\title{
HYGROTHERMAL PERFORMANCE ASSESSMENTS OF TRADITIONAL TIMBER-FRAMED HOUSES IN TURKEY BY NUMERICAL ANALYSIS
}

\author{
SEDA NUR ALKAN ${ }^{1,2} \&$ FATİH YAZICIOĞLU ${ }^{2}$ \\ ${ }^{1}$ Bahçeşehir University, Turkey. \\ 2 İstanbul Technical University, Turkey.
}

\begin{abstract}
The aim of this research is to evaluate the hygrothermal performances of traditional timber-framed houses' exterior walls in Turkey to create a base case scenario of hygrothermal behavior as a datum for conservation and restoration projects. There is a unique range of traditional timber-framed houses in Turkey varied according to geographical, social, economic, and cultural characteristics. They are hybrid constructions whereby an infilled timber-framed system is erected on the masonry walls. They are compositions of rectangular studs of wood and infill materials such as adobe, stone, and brick. Most constructed examples may be classified in groups of four depending on infill materials as follows: (1) timber-framed adobe infill, (2) timber-framed brick infill, (3) timber-framed stone infill, and (4) unfilled timber-framed. Within the scope of the research, one example from each type is selected for hygrothermal performance assessments by applying the simulation program DELPHIN 6.1.1. This research is concentrated on the evaluation of hygrothermal performances of the selected types over 4 years (January 01, 2010-January 01, 2014) by investigating the temperature, relative humidity, U-value, and moisture mass model graphics of the cross-section of the wall samples. 2010 was one of the rainiest years and 2013 was one of the less rainy years in the selected locations for the last 10 years. The findings of this paper indicate that when factors such as construction details, materials, and climatic conditions are varied, there may be humidity-based problems in the selected examples. In that case, intersection points of materials, layers, and their relationships should be re-evaluated to improve the hygrothermal performances of the selected walls for conservation and restoration projects.

Keywords: DELPHIN 6.1.1, hygrothermal performance, infill materials, traditional timber-framed wall.
\end{abstract}

\section{INTRODUCTION}

Moisture-based problems have been one of the critical issues as long-term effects on walls in terms of energy efficiency, indoor environmental quality, and durability. Hygrothermal performance has had direct impacts on the users, material durability, and energy efficiency of a building [1]. A well-performing building façade is based on two critical issues: thermal resistance and vapor permeability [2]. These two issues are also the basic criteria for assessing the hygrothermal performance of an exterior wall. Accordingly, for a well-designed building envelope of nearly zero energy buildings, the hygrothermal design criteria, depending on different material characteristics, should be considered [3].

Nearly, $10 \%$ and $40 \%$ of the building stock consists of historic and traditional buildings; both have a huge potential to reduce energy consumption regarding their physical characteristics [4]. To consider the unique characteristics and conservation principles of traditional houses, the hygrothermal performance is included as a fundamental factor in criteria on building fabric for improvements in energy efficiency [4]. The hygrothermal performance examines construction materials and/or construction elements considering assessments of energy, air balances, and moisture. The assessment of hygrothermal performance requires the evaluation of three flows: (1) heat flowing by conduction, convection, and radiation; (2) moisture flowing by vapor diffusion, convection, and liquid transport; and (3) airflows caused by natural, external, or mechanical forces [5]. Thus, hygrothermal performance assessments 
play a significant role in creating documentation on the effects of temperature and moisture on building components. Due to the physical characteristics of wooden materials, they are affected directly by temperature and moisture. Hygrothermal performance is crucial for traditional timber houses while conserving their energy efficiency and historical value [6].

Turkey has a unique range of traditional architecture that consists of significant examples of wooden material and methods of construction varied according to geographical, social, economic, and cultural characteristics. Traditional Turkish House may be defined as a construction type that responds to the needs of local people with its design decisions while representing traditional Turkish families' lifestyle and culture [7]. In the 17th century, the Ottoman Empire created its unique wooden construction house type known also as the Ottoman House, which was spread over the Anatolia starting from İstanbul [8]. Depending on local characteristics such as geographical, social, cultural features, construction types and infill materials are varied as adobe, brick, and stone [9]. The remarkable examples of traditional timber-framed houses in Turkey are a composition of rectangular studs of wood and infill material such as adobe, stone, brick, or unfilled. Most constructed traditional timber-framed houses in Turkey may be grouped into four types according to infill material as follows: (1) timber-framed adobe infill, (2) timber-framed brick infill, (3) timber-framed stone infill, and (4) unfilled timber-framed. Traditional timber-framed houses examples representing different infill materials are shown in Fig. 1. The construction is composed of rectangular studs of pinewood/beech tree/oak/ash tree, and infill material of adobe, brick, and stone. Wooden diagonals are constructed to cope with the dynamic loads particularly earthquake and wind for stability and durability in the long term. On the other hand, the examples in İstanbul are constructed as unfilled timber-framed. In addition, the example selected from Rize has a unique construction type named as "göz dolma". This construction type is seen in the Eastern part of Turkey's Black Sea Region and is designed as approximately $20 \times 20 \mathrm{~cm}$ squares with timber-framed stone infill.

\subsection{Previous Studies}

Many of the previous studies are focused on the reliability and validity of hygrothermal simulation tools, which are generally tested by comparing their findings with experimental studies. Accordingly, many of these simulation programs are accepted as useful tools for hygrothermal performance analysis of building components. The hygrothermal performances

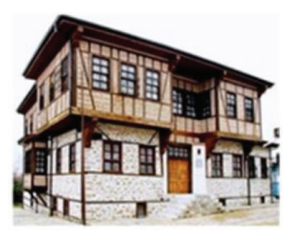

Eskişehir (a)

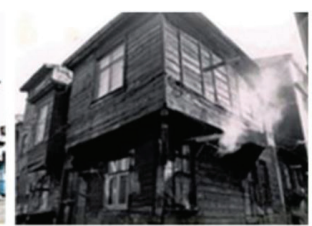

İstanbul (b)

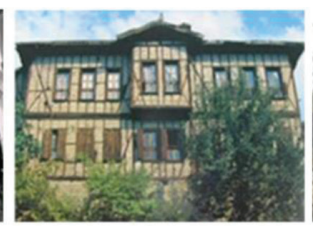

Karabük (c)

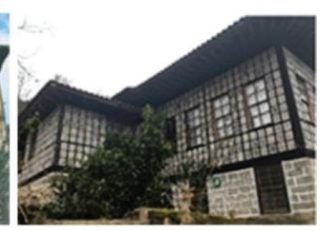

Rize (d)

Figure 1: Traditional timber-framed houses examples representing different infill materials. (a) A picture of traditional timber-framed brick infill in Eskişehir. (Source: sivrihisarweb.tr.); (b) A picture of traditional unfilled timber-framed in İstanbul. (Source: Çobancaoğlu, Güler, and Okyay, 2015.); (c) A picture of traditional timberframed adobe infill in Karabük. (Source: Küçükerman and Güner, 1995.); (d) A picture of traditional timber-framed stone infill in Rize. (Source: Alkan, 2018.) 
of 12 timber-framed wall specimens were examined by both hot box method and MOIST, a hygrothermal simulation tool; the output indicated that the two methods give approximately the same results [10]. The hygrothermal performances of three different timber-framed walls were evaluated considering different thermal insulations and vapor barriers by three different hygrothermal performance simulation tools (1D-HAM, MATCH, and WUFI 2D) and comparison of their output with laboratory test results [11]. The heat transfer coefficient of 12 different timber-framed wall systems was analyzed by comparing the calculation method and hot box-heat flow meter test method results. It was found that the results were nearly the same; they indicated the effects of the insulation materials, moisture content of wooden materials, spacing, and thickness of studs on the heat transfer coefficient of the walls [12].

In the literature, the studies are mainly focused on the hygrothermal performance analysis of insulated timber-framed walls [13-16]. Most of them are conducted with a combination of both experimental and numerical methods and comparison of the results. DELPHIN is one of the most preferred hygrothermal simulation tools. The potential hygrothermal problems of highly insulated timber-framed exterior walls were examined under cold climate conditions by DELPHIN [2]. DELPHIN may be applied as hygrothermal simulation tool for hygrothermal performance analysis of traditional buildings [17]. The simulation tools are applied for heat and air flow analysis, moisture storage, damage risk to specify current conditions, and their effects on conservation and restoration processes.

There appears to be very limited research and published data about hygrothermal performances of walls in Turkey. Most of the existing work is limited to contemporary materials and constructions. Hygrothermal performances of reinforced concrete building envelopes considering different insulation materials, thicknesses, and positions in walls were evaluated by numerical and experimental studies under the climatic conditions of Turkey [18]. The hygrothermal performance simulation tools were explained, and a wall example was analyzed by WUFI 2D regarding important points about effective usage of hygrothermal simulation tools [19]. The hygrothermal performance of a traditional masonry wall was evaluated by WUFI 2D-3 under the climatic conditions of Edirne, Turkey, in terms of temperature, relative humidity and moisture, and water content values [20]. The hygrothermal performances of existing buildings in Çapa, Istanbul were analyzed after applying thermal insulation on the exterior sides of these walls to investigate energy efficiency improvements by WUFI 2D 3.3 [21]. The potential hygrothermal risks of wooden walls, such as cross laminated timber (CLT) and ventilated timber walls in Riva, Istanbul, were examined by WUFI-2D depending on climatic conditions and material properties [22].

Considering the energy consumption of existing buildings, improvements in traditional houses' performances have played a crucial role. However, as Turkey being a seismically active area, the seismic performances of the traditional houses have been mainly researched. There are many studies about traditional houses' seismic performances [23-25]. Especially, after the earthquake of 1999, why and how the traditional houses perform seismically well under lateral loads for many years have been the main research questions in such studies [26].

\subsection{Knowledge gap}

An overview of the previous studies shows that even if there are comprehensive ones on the assessment of the hygrothermal performance of timber-framed buildings and proposals about improvements in hygrothermal performance, there is still a research gap in hygrothermal performance analysis of traditional timber-framed houses in Turkey accounting for their 
unique characteristics regarding material compositions, construction details, and weather conditions. To the authors' knowledge, no previous studies have analyzed the temperature, relative humidity, U-value, and moisture mass model graphics of traditional timber-framed houses in Turkey.

\subsection{Objective}

In the first part of this research, which has already been presented [27], traditional timber-framed house adobe infill was selected as a case study to investigate hygrothermal performance by DELPHIN 6.0.20. This earlier paper generated initial data for a subsequent comprehensive ongoing research that aims to examine the hygrothermal performance of traditional timber-framed houses in Turkey. The present part of the research comprises the results of DELPHIN 6.1.1 simulation analysis to investigate primarily potential hygrothermal risks of the selected traditional timber-framed walls in Turkey. The major interest lies in analyzing the hygrothermal performances of traditional timber-framed houses' walls considering varied infill materials in different climatic conditions. These aspects are examined by the adopted simulation tool to comply with TS 825 : Thermal insulation requirements for buildings, which is one of the current energy performance requirements in Turkey, and investigate potential hygrothermal risks. Within the scope of this study, the cross-section of each wall specimen is evaluated considering their original layers and local climatic conditions to investigate the current situation for each case.

\section{RESEARCH METHODOLOGY}

To investigate the hygrothermal performance of the selected traditional timber-frame walls, a commercial simulation tool, DELPHIN 6.1.1, was used. This method gives the possibility to analyze heat and moisture impacts on building materials and components under real climate conditions by creating 1-D or 2-D models of wall layers. The simulation program is appropriate for the analysis of hygrothermal problems, calculation of thermal bridges and examining insulation proposals. It is capable to account for different types of indoor and outdoor climate conditions. Usually, the hygrothermal performance simulation programs are not concerned with the multilayered conditions of the interior spaces, while taking account of the exterior climatic conditions. In contrast, DELPHIN is capable to analyze the temperature and relative humidity in building components through processes considering the probable variety of parameters for hygrothermal analysis [28].

\subsection{Description of wall specimens}

The hygrothermal performance assessments is conducted on four different walls from the districts of four cities in Turkey where significant examples have been identified: Findıklı, Rize; Safranbolu, Karabük; Sivrihisar, Eskişehir; and Zeyrek, İstanbul. These types are classified as follows: (1) timber-framed stone infill in Findıklı, Rize; (2) timber-framed adobe infill in Safranbolu, Karabük; (3) timber-framed brick infill in Sivrihisar, Eskişehir; and (4) unfilled timber-framed in Zeyrek, İstanbul.

To make the types more recognizable, the wall specimens are named after their districts as Findıkl1, Safranbolu, Sivrihisar, and Zeyrek. For the evaluation of hygrothermal performance, each type is modified as a $150 \times 150 \mathrm{~cm}$ wall specimen. The timber-frames of these wall specimens are shown in Fig. 2. 


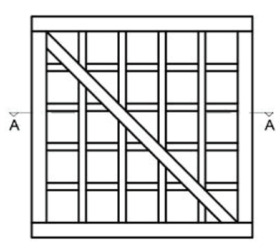

Fındıklı

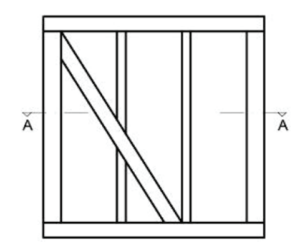

Safranbolu
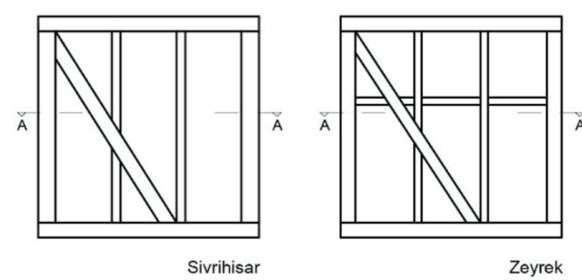

Figure 2: Elevation drawings of the timber-framed of wall specimens.

The walls of traditional timber-framed houses are varied depending on the wood material, size, configuration/layout, infill material, and covering material. Within the scope of this paper, the most commonly constructed wall types are selected as wall specimens. To investigate the effects of layer variations on the hygrothermal performances of the walls, cross-section A-A is taken into consideration as shown in Fig. 2. The section drawings of the wall specimens indicating layers and materials are presented in Fig. 3. Detailed information about materials is given in Table 1.

\subsection{Assigning material properties and sizing layers}

The output from the hygrothermal performance simulations is based on the inputs of (1) geometry of enclosure, (2) boundary conditions (interior, exterior, indoor, and outdoor surface transfer), and (3) material properties (bulk density, porosity, specific heat capacity, thermal conductivity, water vapor permeability, water absorption coefficient, moisture stor-

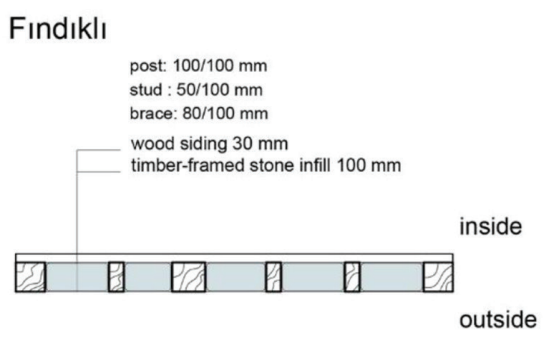

Section A-A

\section{Safranbolu}

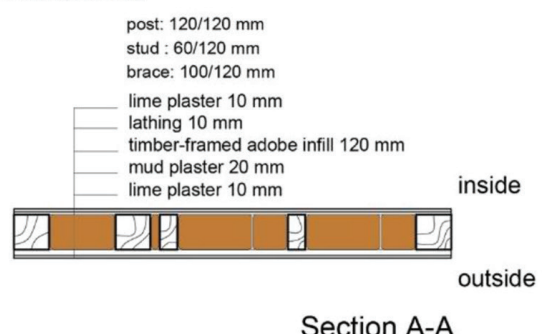

Zeyrek

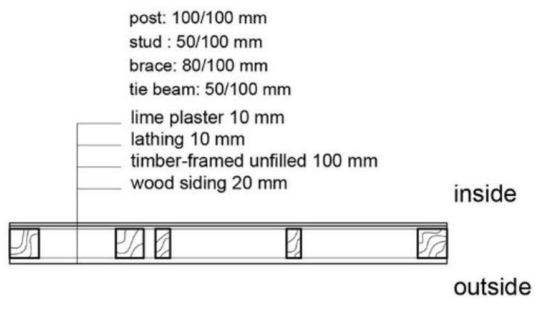

Section A-A

Section A-A

Figure 3: Cross-section drawings of the wall specimens. 


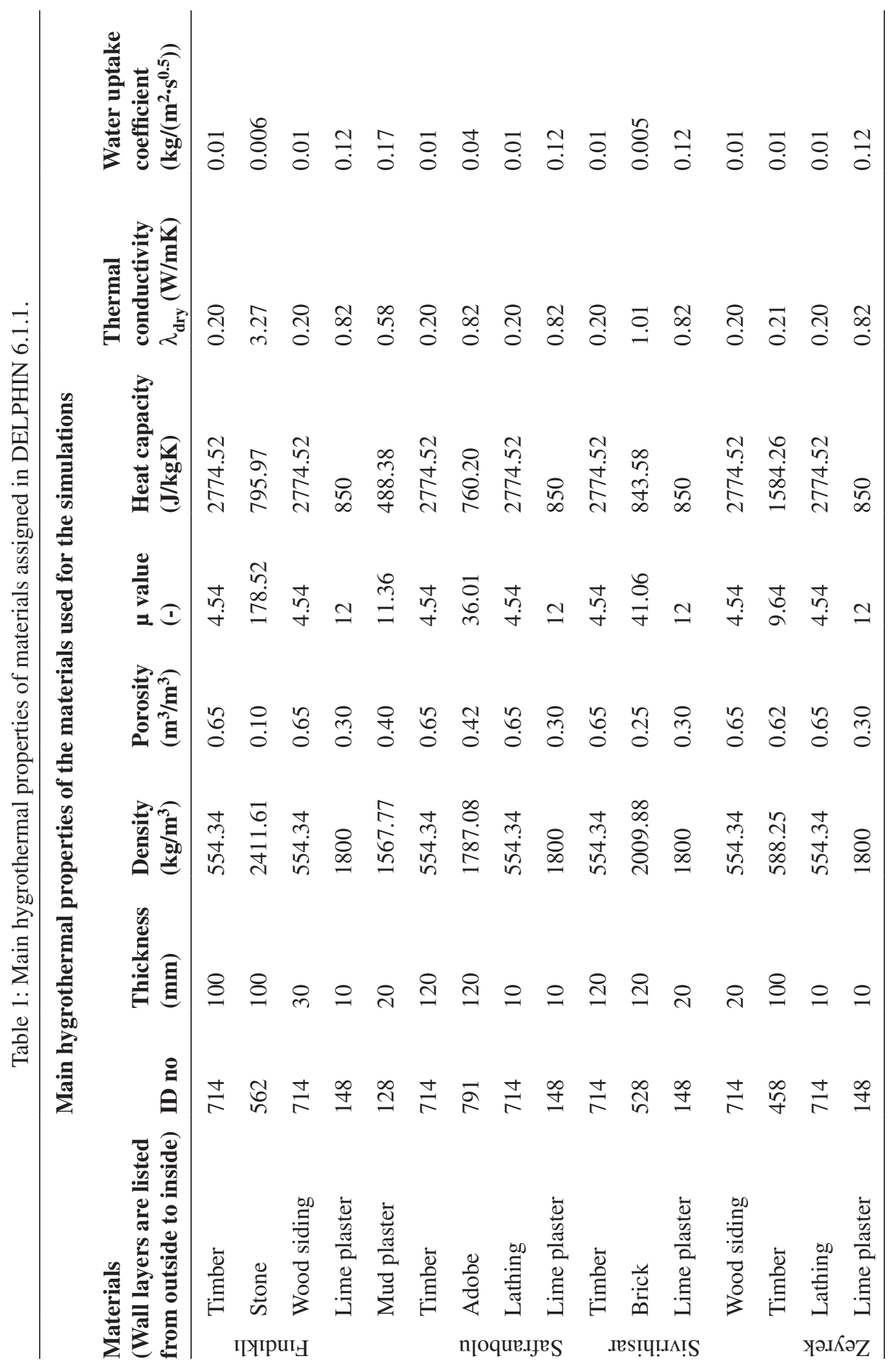


age functions, and reference values) [5]. After modeling the sections, the wall specimens are defined by sizing layers and assigning material properties as given in the Table 1 (two decimal places for values are shown and values are not rounded up or down). Due to the exactly the same materials not being included in the simulation program database, their properties are selected by comparing the main hygrothermal properties of materials used in DELPHIN 6.1.1 with the corresponding values in TS 825. In some cases, the materials are not included in TS 825, then their properties are assigned based on the program data. As it is seen in the table, the materials have different hygrothermal properties. Thus, these properties may affect the hygrothermal performance of wall specimens depending on construction details.

\subsection{Boundary conditions}

Modeling started with the definition of weather data for the location. The weather data for outdoors are provided by DELPHIN 6.1.1 in TRY format for some cities in European countries. However, the program does not include weather data for Rize, Karabük, Eskişehir, and İstanbul. Therefore, weather data for these cities are imported to the files to reflect realistic weather conditions during the simulation processes. Marmara, Aegean, Mediterranean, Central Anatolia, Southeastern Anatolia, Eastern Anatolia, and Black Sea are the seven different geographical regions in Turkey that have their own social, cultural, geographical, economic, and architectural features. Rize is placed in the east part of the Black Sea Region. It has rainy and humid climate throughout a year and, therefore, the region is covered with dense forest areas. Although Karabük is located in the west part of the Black Sea Region, its weather is not same with that of Rize. The climate of Karabük is affected by the weather of the Central Anatolia Region; it has a climate between humid and continental due to its geographical location. Eskişehir is in the northwest part of Central Anatolia Region. It has a continental climate characterized by significant temperature difference between day and night. İstanbul is placed in the north part of Marmara Region where Bosphorus is located. The city has Mediterranean climate.

The boundary conditions need to be specified for simulation purposes. For the outdoor conditions, the imported weather files are assigned. Those of the indoor spaces are assigned according to TS 825 criteria: indoor temperature of $20^{\circ} \mathrm{C}$ and relative humidity of $65 \%$ for all the simulation processes. The initial temperature is set at $20^{\circ} \mathrm{C}$ and the relative humidity at $80 \%$ as the default initial conditions of the simulation program. Due to the north façade's weather being affected much more than the other orientations, it is assumed that the walls are facing northwards. Heat conduction, vapor diffusion, short-wave solar radiation, long-wave radiation exchange, and winddriven rain (DIN EN ISO 15927-3) are taken into consideration during the simulation processes. The simulation covered 4 years starting from January 01, 2010 and finishing on January 01, 2014. 2010 was one of the rainiest years, while 2013 was one of the less rainy years in these regions over the last 10 years. Therefore, U-values are evaluated considering these years in Table 2. Furthermore, the temperature, relative humidity, and moisture mass model graphics are analyzed as outputs of the simulations. Within the scope of this study, these values are shown as averages over the whole section A-A of each wall, they are not obtained for specific points on inside and outside surfaces separately. This issue may be considered in future, more extensive studies.

\subsection{Hygrothermal analysis: results and discussion}

Temperature and relative humidity, by affecting each other, are two primary factors of mould growth risk in buildings. The effectiveness of moisture control is directly related with temperature and relative humidity values in construction materials and building components. The 
Table 2: Temperature, relative humidity, thermal conductivity, and U-values.

\begin{tabular}{|c|c|c|c|c|c|}
\hline 总 & Date & $\begin{array}{l}\text { Temperature } \\
\left({ }^{\circ} \mathrm{C}\right)\end{array}$ & $\begin{array}{l}\text { Relative humidity } \\
(\%)\end{array}$ & $\begin{array}{l}\text { Thermal } \\
\text { conductivity } \\
\lambda \\
(\mathrm{W} / \mathrm{mK})\end{array}$ & $\begin{array}{l}\text { U-value } \\
\left(\mathbf{W} / \mathbf{m}^{2} \mathbf{K}\right)\end{array}$ \\
\hline \multirow{9}{*}{ 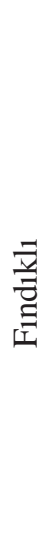 } & 21.03 .2010 & 16.44 & 43.83 & 0.23 & 1.36 \\
\hline & 21.06 .2010 & 23.33 & 59.15 & 0.24 & 1.40 \\
\hline & 22.09 .2010 & 20.60 & 83.48 & 0.25 & 1.44 \\
\hline & 21.03.2013 & 16.44 & 43.83 & 0.23 & 1.36 \\
\hline & 21.06 .2013 & 23.33 & 59.15 & 0.24 & 1.40 \\
\hline & 22.09 .2013 & 20.60 & 83.49 & 0.25 & 1.44 \\
\hline & 21.03.2010 & 15.82 & 54.23 & 0.82 & 2.70 \\
\hline & 21.06 .2010 & 17.81 & 64.33 & 0.82 & 2.70 \\
\hline & 22.09 .2010 & 20.36 & 74.02 & 0.82 & 2.70 \\
\hline \multirow{3}{*}{ 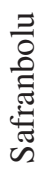 } & 21.03.2013 & 15.83 & 54.19 & 0.82 & 2.70 \\
\hline & 21.06.2013 & 17.81 & 64.33 & 0.82 & 2.70 \\
\hline & 22.09 .2013 & 20.36 & 74.02 & 0.82 & 2.70 \\
\hline \multirow{10}{*}{ : } & 21.03 .2010 & 29.23 & 20.87 & 0.21 & 1.20 \\
\hline & 21.06 .2010 & 17.78 & 64.48 & 0.24 & 1.33 \\
\hline & 22.09 .2010 & 14.30 & 84.51 & 0.25 & 1.36 \\
\hline & 21.03 .2013 & 29.22 & 20.93 & 0.21 & 1.20 \\
\hline & 21.06.2013 & 17.78 & 64.48 & 0.24 & 1.33 \\
\hline & 22.09 .2013 & 14.30 & 84.51 & 0.25 & 1.36 \\
\hline & 21.03 .2010 & 31.18 & 27.49 & 0.22 & 1.25 \\
\hline & 21.06 .2010 & 22.39 & 65.71 & 0.24 & 1.33 \\
\hline & 22.09 .2010 & 17.41 & 65.52 & 0.24 & 1.33 \\
\hline & 21.03.2013 & 31.19 & 27.47 & 0.22 & 1.25 \\
\hline \multirow{2}{*}{ 离 } & 21.06.2013 & 22.39 & 65.71 & 0.24 & 1.33 \\
\hline & 22.09 .2013 & 17.41 & 65.51 & 0.24 & 1.33 \\
\hline
\end{tabular}


temperature profile has a critical impact on moisture behavior throughout the wall system components. Because of temperature dominating relative humidity, the moisture accumulation in components of wall systems is an issue depending on widely varied temperature profiles. There are many reasons of mould growth risk in buildings, but it is underlined that mould growth risk mostly occurs when the relative humidity gets over $80 \%$ [29]. Mould growth in buildings is a major risk factor of both physiological and visual deterioration of buildings. It has damaging effects on materials and components of buildings as well as occupants' health by changing the air quality of buildings [30].

Figure 4 shows the temperature and relative humidity values relationships of section A-A of each wall. The red lines represent temperature values, and the blue ones indicate relative humidity starting from January 01, 2010 until January 01, 2014; that is, over 1460 days. Throughout the simulation processes, the relative humidity values are over $80 \%$, which may cause critical mould growth risks within the wall systems as described in what follows. The temperature and relative humidity graphs for the Findıklı section A-A indicate that the relative humidity varies between $70 \%$ and $80 \%$, while the temperature range is $20-0{ }^{\circ} \mathrm{C}$ during the fall and winter seasons. The temperature and relative humidity graphs for the Safranbolu
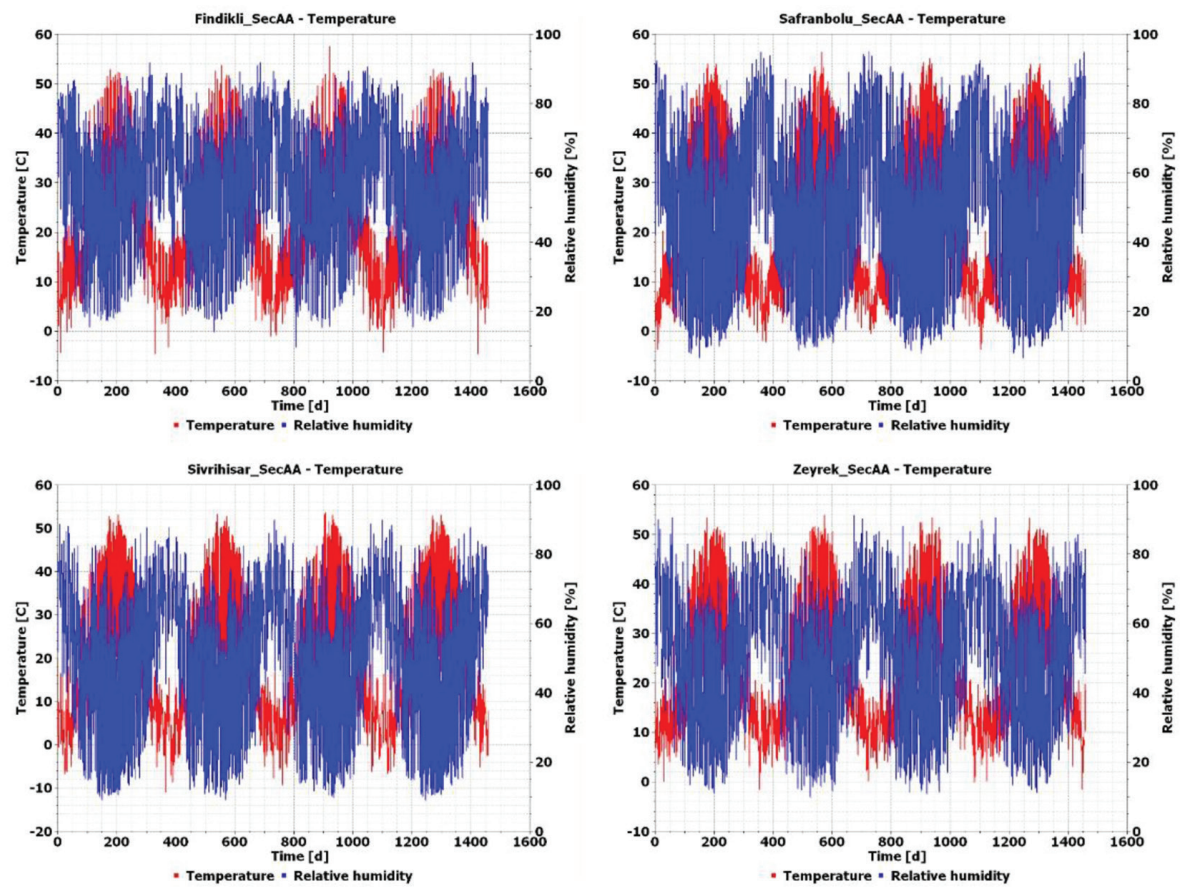

Figure 4: Temperature and relative humidity relationships of the section A-A of each wall specimen. 
section A-A indicate that the relative humidity gets over $80 \%$, while the temperature range is approximately $20-0{ }^{\circ} \mathrm{C}$ during the fall and winter seasons. Also, in winter periods, the relative humidity gets closer to $90 \%$ while the temperature range is $10-0{ }^{\circ} \mathrm{C}$. As seen in the results for the Sivrihisar section A-A, the relative humidity is mostly above $80 \%$ and the temperature range is approximately 20 -below $0{ }^{\circ} \mathrm{C}$ in the fall and winter seasons. In fall and winter periods, for the Zeyrek section A-A, the relative humidity gets closer to $80 \%$ and the temperature range is approximately $20-0{ }^{\circ} \mathrm{C}$. A common feature for all sections is that relative humidity and temperature do not reach stability and their range increases or decreases in short time periods.

The U-value is calculated according to the equation given by TS 825 :

$$
\frac{1}{U}=R_{s i}+R+R_{s e}
$$

where

$$
R=\frac{d_{1}}{\lambda_{h_{1}}}+\frac{d_{2}}{\lambda_{h_{2}}}+\ldots+\frac{d_{n}}{\lambda_{h_{n}}} .
$$

In Eqn (2), $d_{1}, d_{2}, \ldots, d_{n}$ represent the layer thicknesses and $\lambda_{h 1}, \lambda_{h 2}, \ldots, \lambda_{h n}$ the corresponding thermal conductivities. The thermal resistances due to convection and conduction at the internal and external wall surfaces $R_{s i}$ and $R_{s e}$ were taken as 0.13 and $0.04 \mathrm{~m}^{2} \mathrm{~K} / \mathrm{W}$, respectively. Rize and İstanbul are placed in the 2nd zone and the expected U-values should not exceed $0.57 \mathrm{~W} / \mathrm{m}^{2} \mathrm{~K}$; Karabük and Eskişehir are placed in the $3 \mathrm{rd}$ zone and the expected U-values should not exceed $0.48 \mathrm{~W} / \mathrm{m}^{2} \mathrm{~K}$ [31]. In this work, the U-values were evaluated by entering the given values of the various parameters into Eqn (1), and they are presented in Table 2 (two decimal places for values are shown and values are not rounded up or down). The program calculates hourly data in every 1.5 days. Therefore, the dates shown in the table were selected considering astronomical seasons and days of measurement. As explained previously, the years were chosen according to rainfall. It is seen that the temperature and relative humidity have some impact on the average thermal conductivity. As seen in Table 2, the U-values of the wall specimens are not close to recommended values in TS825. Considering these results, the U-values of the studied wall types need to be improved considering the historical, architectural, cultural, and social values of these buildings. For this to be a comprehensive study, it needs to be pursued as a multidisciplinary topic in the long term.

Figure 5 displays the plots of moisture mass for sections A-A of the wall specimens indicating the total mass density of liquid water, water vapor, and ice at the end of the simulation processes. The plots are obtained directly from DELPHIN 6.1.1. As seen, in order to exhibit more clearly the moisture mass through the wall models, the plots are automatically expanded along the $\mathrm{x}$-axis. The $\mathrm{x}$-axis and the $\mathrm{y}$-axis are parallel, respectively, to the depth and the length of the walls. For the Findiklı A-A section, the moisture mass is approximately $20 \mathrm{~kg} /$ $\mathrm{m}^{3}$ through the infill parts. The moisture mass is over $60 \mathrm{~kg} / \mathrm{m}^{3}$ in wooden studs, and it is closed to $120 \mathrm{~kg} / \mathrm{m}^{3}$ in some parts of wood siding. In the Safranbolu A-A section, the moisture mass is over $30 \mathrm{~kg} / \mathrm{m}^{3}$ through the infill and mud plaster parts. The moisture mass is approximately $70 \mathrm{~kg} / \mathrm{m}^{3}$ in wooden studs and lathing. For the lime plaster on the outside, the moisture mass is around $10 \mathrm{~kg} / \mathrm{m}^{3}$, and for the lime plaster on the inside, the moisture mass range is $10-40 \mathrm{~kg} / \mathrm{m}^{3}$. The moisture mass is approximately $50 \mathrm{~kg} / \mathrm{m}^{3}$ in infill parts and it is over $50 \mathrm{~kg} / \mathrm{m}^{3}$ in wooden studs of the Sivrihisar A-A section. In some intersection points of 

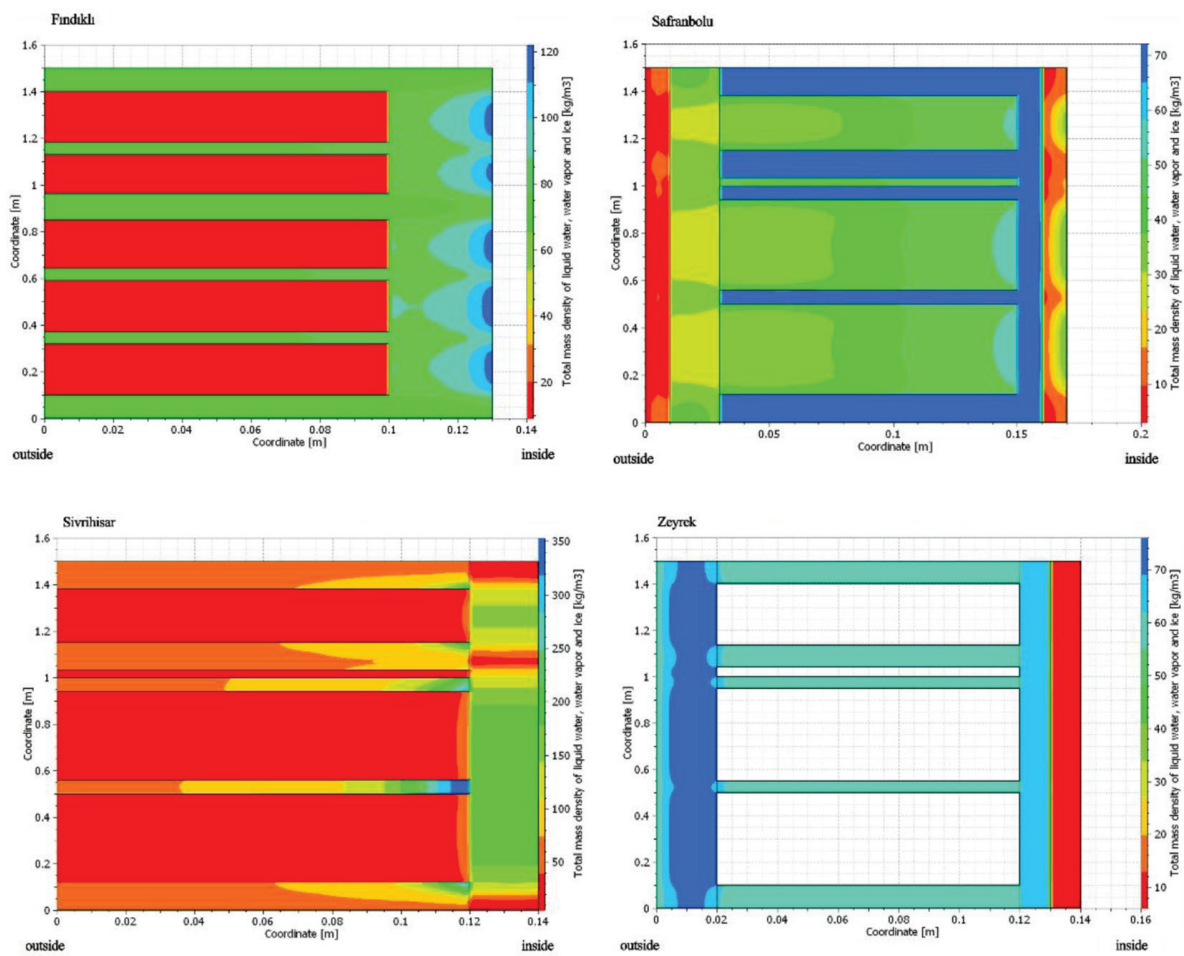

Figure 5: Moisture mass models of the section A-A of each wall specimens; the plots show the cross-section/plan view of the wall specimens.

wooden studs with lime plaster, the moisture mass is over $300 \mathrm{~kg} / \mathrm{m}^{3}$. For the lime plaster, the moisture mass range is $50-250 \mathrm{~kg} / \mathrm{m}^{3}$. In Zeyrek Section A-A, the moisture mass is over 60 $\mathrm{kg} / \mathrm{m}^{3}$ in wooden studs and lathing. In some parts of wooden siding, the moisture mass is close to $70 \mathrm{~kg} / \mathrm{m}^{3}$. For the lime plaster, the moisture mass is around $10 \mathrm{~kg} / \mathrm{m}^{3}$. As is indicated in all plots, moisture commonly accumulates (mostly over $60 \mathrm{~kg} / \mathrm{m}^{3}$ ) in wooden parts of the walls systems, that is, the wooden studs. Consequently, the intersection points of wooden studs, infill materials, and covering layers are critical in terms of addressing humidity-based problems, which depend on their different moisture mass values.

\section{CONCLUSION AND FUTURE RESEARCH}

This part of an ongoing study presents the evaluation of hygrothermal performances of traditional timber-framed houses' walls in Turkey by the simulation program DELPHIN 6.1.1. The results show that there may be humidity-based problems in the four selected examples. In this respect, it is crucial to pay attention to intersection points of different materials and their relationships to improve hygrothermal performances. The results need to be checked by experimental methods to confirm their reliability, validity, and applicability. Therefore, this study is planned to be continued with experimental research and comparison of measurements with simulation results. One of the expected outcomes of this paper is to open a discussion on the hygrothermal performances of traditional timber-framed houses considering them as architectural heritage. 


\section{REFERENCES}

[1] Gasparin, S., Berger, J., Dutykh, D. \& Mendes, N., Solving nonlinear diffusive problems in buildings by means of a spectral reduced-order model. Journal of Building Performance Simulation, 12(1), pp. 17-36, 2019. https://doi.org/10.1080/19401493.2 018.1458905

[2] Pihelo, P. \& Kalamees, T., The effect of thermal transmittance of building envelope and material selection of wind barrier on moisture safety of timber frame exterior wall. Journal of Building Engineering, 6, pp. 29-38, 2016. https://doi.org/10.1016/j. jobe.2016.02.002

[3] Pihelo, P., Kikkas, H. \& Kalamees, T., Hygrothermal performance of highly insulated timber-frame external wall. Energy Procedia, 96, pp. 685-695, 2016. https://doi. org/10.1016/j.egypro.2016.09.128

[4] Webb, A.L., Energy retrofits in historic and traditional buildings: A review of problems and methods. Renewable and Sustainable Energy Reviews, 77, pp. 748-759, 2017. https://doi.org/10.1016/j.rser.2017.01.145

[5] Delgado, J., Barreira, E., Ramos, N.M.M. \& de Freitas, V.P., Hygrothermal Numerical Simulation Tools Applied to Building Physics, Springer-Verlag: Berlin, Heidelberg, 2013.

[6] Hola, A. \& Czarnota, M., Analysis of the possibilities of improving timber-framed wall thermal insulation with regards to historical buildings. Procedia Engineering, 111, pp. 311-316, 2015. https://doi.org/10.1016/j.proeng.2015.07.094

[7] Kuban, D., The Turkish Hayat House (in Turkish), T.C. Ziraat Bankası Kültür Yayınları, 1995.

[8] Şahin Güçhan, N., History and characteristics of construction techniques used in traditional timber Ottoman houses. International Journal of Architectural Heritage, 12(1), pp. 1-20, 2018. https://doi.org/10.1080/15583058.2017.1336811

[9] Yazıcioğlu, F. \& Alkan, S., An analysis on building elements of a wooden structured granary "Serender" in Turkey's Eastern Black Sea Region. Archnet-IJAR: International Journal of Architectural Research, 14(1), pp. 77-89, 2019. https://doi.org/10.1108/ arch-04-2019-0087

[10] Zarr, R.R., Burch, D.M. \& Fanney, A.H., Heat and Moisture Transfer in Wood-Based Wall Construction: Measured Versus Predicted, NIST Building Science Series 173, Washington: U.S. Government Printing Office, 1995.

[11] Kalamees, T. \& Vinha, J., Hygrothermal calculations and laboratory tests on timberframed wall structures. Building and Environment, 38(2003), pp. 689-697, 2003. https://doi.org/10.1016/s0360-1323(02)00207-x

[12] Liu, M., Sun, Y., Sun, C. \& Yang, X., Study on thermal insulation and heat transfer properties of wood frame walls. Wood Research, 63(2), pp. 249-260, 2018.

[13] Pihelo, P., Kikkas, H. \& Kalamees, T., Hygrothermal Performance of Highly Insulated Timber-frame External Wall. Energy Procedia, 96(2016), pp. 685-695, 2016. https:// doi.org/10.1016/j.egypro.2016.09.128

[14] Martinez, R.G., Hygrothermal assessment of a prefabricated timber-frame construction based in hemp. Procedia Environmental Sciences, 38, pp. 729-736, 2017. https://doi. org/10.1016/j.proenv.2017.03.155 
[15] Fu, H., Ding, Y., Li, M., Li, H., Huang, X. \& Wang, Z., Research on thermal performance and hygrothermal behavior of timber-framed walls with different external insulation layer: Insulation cork board and anti-corrosion pine plate. Journal of Building Engineering, 28, p. 101069, 2020. https://doi.org/10.1016/j.jobe.2019.101069

[16] Schjøth Bunkholt, N., Rüther, P., Gullbrekken, L. \& Geving, S., Effect of forced convection on the hygrothermal performance of a wood frame wall with wood fibre insulation. Building and Environment, 195, p. 107748, 2021. https://doi.org/10.1016/j. buildenv.2021.107748

[17] Claude, S., Ginestet, S., Bonhomme, M., Escadeillas, G., Taylor, J., Marincioni, V., Korolija, I. \& Altamirano, H., Evaluating retrofit options in a historical city center: Relevance of bio-based insulation and the need to consider complex urban form in decision-making. Energy \& Buildings, 182, pp. 196-204, 2018. https://doi.org/10.1016/j. enbuild.2018.10.026

[18] Umaroğulları, F., Betonarme Düşey Yapı Kabuğunda Yalıtımın Yerinin ve Kalınlı̆̆ının, Nem Denetimi Açısından Deneysel ve Sayısal Değerlendirmesi (in Turkish), PhD Thesis, Trakya University, 2011.

[19] Edis, E. \& Kuş, H., Bina kabuğunun nemsel-1sıl performansının bilgisayar benzetimi ile belirlenmesi (in Turkish). Gazi Üniv. Müh. Mim. Fak. Dergisi, 29(2), pp. 311-320, 2014. https://doi.org/10.17341/gummfd.16852

[20] Mıhlayanlar,E. \& Umaroğulları, F., Kalker taş duvarlarda sıcaklık ve nem performansının incelenmesi. Çukurova Üniversitesi Mühendislik Mimarlık Fakültesi Dergisi, 31(1), pp. 313-321, 2016. https://doi.org/10.21605/cukurovaummfd.317844

[21] Ekşi, A., Mevcut Binaların Cephelerinde Dıştan Isı Yalıtımı Uygulamalarının Ístanbul'da Alanda Incelenmesi ve Higrotermal Performansin Benzetimle Değerlendirilmesi (in Turkish), Master Thesis, İstanbul Technical University, 2016.

[22] Samanc1, B., Ahşap Dış Duvarların İstanbul'daki Uygulamalar Üzerinden Incelenmesi, Isıl ve Nemsel Performansin Benzetim ile Değerlendirilmesi (in Turkish). Master Thesis, İstanbul Technical University, 2019.

[23] Doğangün, A., Tuluk, Ö., Livaoğlu, R. \& Acar, R., Traditional wooden buildings and their damages during earthquakes in Turkey. Engineering Failure Analysis, 13, pp. 981-996, 2006. https://doi.org/10.1016/j.engfailanal.2005.04.011

[24] Şahin Güçhan, N., Observations on earthquake resistance of traditional timber-framed houses in Turkey. Building and Environment, 142(2), pp. 840-851, 2007. https://doi. org/10.1016/j.buildenv.2005.09.027

[25] Aktaş, Y.S., Evaluation of Seismic Resistance of Traditional Ottoman Timber Frame Houses, Doctoral Thesis, Middle East Technical University, 2011.

[26] Köylü, A., Geleneksel Yapıların Yatay Yükler Etkisinde Incelenmesi (in Turkish), Master Thesis, Eskişehir Osmangazi University, 2008.

[27] Alkan S.N. \& Yazıcıoğlu, F., Hygrothermal performance analysis of traditional timberframed houses in Turkey. WIT Transactions on the Built Environment, WIT Press, Vol. 195, pp. 125-135, 2020.

[28] Tijskens, A., Janssen, H. \& Roels, S., A simplified dynamic zone model for a probabilistic assessment of hygrothermal risks in building components. Energy Procedia, 132, pp. 717-722, 2017. https://doi.org/10.1016/j.egypro.2017.10.012 
[29] Chen, G., Luo, Q., Guo, X., Liu, X., Tu, M. \& He, Y., Study on mould germination risk in hydroscopic building wall. Procedia Engineering, 205, pp. 2712-2719, 2017. https://doi.org/10.1016/j.proeng.2017.10.193

[30] Chang, S.J. \& Kim, S., Hygrothermal performance of exterior wall structures using a heat, air and moisture modeling. Energy Procedia, 78, pp. 3434-3439, 2015. https://doi.org/10.1016/j.egypro.2015.12.328

[31] Türk Standardları Enstitüsü. TS825 Binalarda 1S1 yalıtım kuralları (in Turkish) (Thermal insulation requirements for buildings), 2013 